\title{
STEREOTYPING OF INFERIOR-SUPERIORITY IN “CAESAR AND CLEOPATRA" (1945) DRAMA BY GEORGE B SHAW
}

\author{
Zulfiana Dessyka Putri \\ Universitas Karimun (UK), Kepri, Indonesia \\ zulfianadessykaputri@gmail.com
}

\begin{abstract}
This article aimed to reveal various forms of arbitrary stereotypes between who is perceived as superior and who is perceived as inferior. By taking data from the play Caesar and Cleopartra (1945) by George B Shaw, the researcher examined various discriminatory and tendentious stereotyping phenomena. Although this drama was raised and raised by the western world by involving the east in it, this is what then triggers a new problem of discriminatory inequality between the west and the east which then forms discriminatory perceptions. By using the postcolonial approach, especially Edward Said's orientalism, the researcher uncovers various myths and phenomena. The method used in this research is a qualitative method with a library data collection system and deep critical analysis. The results of this study indicate that the form of incidental and oriental stereotyping is clearly seen through the depiction in the story. The West through the character of Caesar who represents white superiority carries out various orientalist practices on the character of Cleopatra as a representation of the east. All are quoted in their actions, attitudes, character, and disposition.
\end{abstract}

Keyword: Stereotyping, Inferior, Superior, Orientalism

\section{INTRODUCTION}

Malaysia, Singapore, Pakistan, and Bangladesh are part of the British Commonwealth Nations. The nations happened after their independence and the British postcolonial. Postcolonial is events happen after the colonization. Postcolonial is an approach for literary analysis in particular written literature. Above colonization happen among west and east. It's their willingness to join the nations. The colonization of British Westerners assumes that commonwealth nations are developed countries because of the Occident. Their assumption towards Asian need their help to be developed countries can be studied as proposed by Edward Said (1978).

Stereotypes are sometimes deliberately constructed to build superiority "Did they expect you to get married at 23?" Or "Your parents must be really strict, why aren't you a doctor or a lawyer? Are you good at math?" Those are examples of Asian stereotypes by white people 
on Lili Singh's youtube channel with episode 'Real things white people have said to me'. Above examples contain orientalism because those sentences are said to Asian by white people. According to Said (1978) orientalism is the way westerners see easterners at certain points. How they see orient is affected by the colonization of the west. Orientalism is the ineradicable distinction between western superiority and oriental inferiority.

The data source is drama of Caesar and Cleopatra. Caesar and Cleopatra is a drama that was written in 1898 by George Bernard Shaw. He is an Irish playwright, literary critic, and socialist propagandist. This drama tells the fictional relationship story between Julius Caesar and Cleopatra. In March 1899, this play written was first performed at the Theatre Royal, Newcastle. Nil Melikesi is the first adaption as movie in 1945 .

There are many previous studies about Orientalism. Hasani (2020) from Diponegoro University discussed Orientalism in The Painted Veil. That article analyzed how West describes the East and how the East looks at the west. Also the conflicts, settings, and characters are analyzed. The data source is in novel by William Somerset Maugham. For that article, library research method is used. The results are there are found British view towards Chinese, the policy of British in China, the purpose of conquering China, and comparison the West religion and the East religion.
Maliyana (2013) from University of Education Bandung also studied Orientalism in novel by Alan Drew entitled Gardens of Water. That article tried to analyze how Alan Drew, as the western author described the East culture in that novel. Qualitative descriptive is used as the method and also content analysis approach. In that article, there are found the results that the representation of non-western people and cultures confirms orientalist point of view that puts East and the West in a binary opposition and east as inferior. There is also found that the author uses typical stereotyping to describe east like rude, untrustworthy, barbaric, and traditional, and also patriarchy.

From previous research, it can be seen that the Orientalism issue is still happening and can be seen in social media, books, and paper news. The similarity of this research and above are the theory which is Orientalism by Edward Said (1978). Another similarity is the aim which is to analyze and describe the west towards east and vice versa. The differences are the data source. Above articles used novels, but this research used drama script. For further analysis of Orientalism, this research applied theory from Said (1978). Caesar and Cleopatra (1945) Drama by George Bernard Shaw is used as the data source. The purpose of this research is to find and analyze how the West describes the East and how the West describe the western character through Caesar. 


\section{LITERATURE REVIEW}

\subsection{Orientalism}

Orientalism is an approach created by Edward Said (1978). Said (1978) stated that orientalism is the abstraction between 'orient' and 'occident'. It means that how the east or orient sees west or occident and vice versa. In this approach, it is explained that The Orient is menial while The Occident is stout that can conquer The Orient. It is seen that The Orient barbaric, rude, patriarchy, and childish by The Occident. Also, the Occident influences not only cultural but also ideology, politic, geography, and power. European or the West or the Occident declared themselves as superior race and has more power. Moosavinia (2011) also stated that the Orient is dominated by the West in order to construct a force between The Orient and The Occident. It can be concluded that Orientalism is a study to analyze and describe the West's representation towards the Orient/east that the main purpose is controlling, constructing and representing them.

Orientalism comes from the words "orient" and "ism." The word ism comes from the Dutch (Latin: isma, English: ism), which means a doctrine, theory, or system (establishment, belief, and system). Therefore, etymologically, orientalism can be interpreted as the science of the east or the study of the eastern world. Orientalist comes from the English word "orientalist," which means people who study art, language, and other things related to Eastern countries.
So it can be concluded at the etymological level that orientalism is an understanding of the east, while orientalists are people who carry out oriental studies or who carry this understanding.

\subsection{Previous Study}

Research related to Post colonialism is a topic that never stops being discussed. Research conducted by Piscesco \& Arianto (2021) which analyzes apartheid politics against Africans in the story of Escape from Pretoria. This study raises the theme of the African black race under the domination of white people. Kinanti, A. L., \& Daulay, R. (2020) also analyzed the construction of inferiority but focused more on the abuse of children in the Rainbow Rowell's Eleanor and Park story. Daulay, R., \& Arianto, T. (2020) conducted research from a postcolonial perspective on the work of AA.Navis The collapse of our surau. This study uses the Edward Said approach in the hybridity framework.

\section{RESEARCH METHOD}

This research is accomplished by exploring the data in the form of script. To explain the orientalism issue and analyze it, descriptive method is used. The data are script therefore qualitative research is applied. Creswell (2014) stated that qualitative research is an extensive classification of research design or example that bring out visual, verbal, olfactory, tactile, and gustatory data in the form of descriptive narratives like recordings, field notes, and any 
other transcriptions for instance written records.

Close reading method is used to collect the data theorized by Snow \& O'connor (2016). This method needs people to find meaning from texts by analyzing how language is used in the paragraph. After that, to collect the data, the drama's script is downloaded. Next, the script is read until the end. After that, all the orientalism issue is written down. Finally, the data will be analyzed. Hence, this research is descriptive qualitative study.

\section{DISCUSSION}

Caesar and Cleopatra is a drama that was written in 1898 by George Bernard Shaw. This drama tells how Caesar tutors Cleopatra to be a Queen and to use political power. George Bernard Shaw is an Irish that wrote this drama. This drama describes two sides, they are the West and the East. The protagonists are Cleopatra as the Orient and Caesar as the West. Shaw described Cleopatra as innocent young girl, childish, and barbaric. And the author described Caesar as intelligence, patience, good and kind hearted ruler. The characterization by Shaw can be misleading because he is not Orient. He didn't experience the culture of the Orient rather used his own knowledge and research. Initiating from this reason, this research means to find how the author represents the East in the drama.

\subsection{HOW THE OCCIDENT AUTHORS DESCRIBE THE ORIENT}

How the author describes the orient can be seen when the King of Egypt was Ptolemy Dionysus. Ptolemy Dionysus is Cleopatra's brother. Ptolemy was described as childish, had habit of leading strings, impotence and petulance. Ptolemy was way too young to rule the Kingdom. He was 10 years old. He even was not ready to be a King. He even could not remember his line when he gave speech and announcement while Caesar was described as a patience ruler, kind, and a hard worker. The Egypt Kingdom was also described poor and didn't have proper management as below quoted:
Pothinus : "The King's treasury is poor, Caesar."
Caesar : "Yes: I notice that there is but one chair in it."

The people of Alexandrian and the court assembled to receive Ptolemy. There were Ptolemy's tutor; Theodotus, and Achillas; the general of Ptolemy's troops. And then Caesar came in asked who the King was, the man or the boy. Then Caesar asked some money. The situation in that scene seemed untidy. The palace looked empty with no furniture and people had no respect for the king, Ptolemy when Pothinus; Ptolemy's guardian pushed him to sit down.

The heir was supposed for Cleopatra as she was older than Ptolemy. But because she is a woman, she had to be accompanied by a man; her younger brother. This 
shows that author described the East as patriarchal where woman cannot be a leader whilst Caesar as the Occident supported and helped Cleopatra to reach her position as a Queen. Shaw also wrote the East barbaric. It is shown many times how people of Egypt used joke to kill somebody by cutting their head off. Ptolemy, Cleopatra, and also Pothinus had used that joke. Even with their own blood, Cleopatra's father killed her sister because she rebelled against him and took the throne from him. Pothinus used that joke referred to kill Cleopatra.

Pothinus : "Achillas: if you are not a fool, you will take that girl whilst she is under your hand."

Rufio : "Why not take Caesar as well, Achillas?"

It is also told that the politic in that time used violence or murdered someone to a temporary anger. For instance when Ptolemy wanted to kill the guard and he did it and Caesar wasn't pleased about it. Cleopatra had also said to murder people as below

Cleopatra: of course not. I am the queen. I shall live in the palace at Alexandria when I have killed my brother, who drove me out of it. when I am old enough I shall do just what I like. I shall be able to poison the slaves and see them wriggle and pretend to Ftatateeta that she is going to be put into the fiery furnace"

Shaw also made Cleopatra and her brother as a married couple.
Caesar was shocked when he heard Cleopatra mentioned her brother as her husband. This shows how inferior the East in humanity and civilization.

Cleopatra: I am not afraid. A queen must not be afraid. Eat my husband there, if you like: he is afraid.

Caesar : Your husband! What do you mean?

Cleopatra : That little thing.

All the Romans were shocked and said that was barbarian to marry siblings. And Caesar as the smart person saw it as a chance for Cleopatra to be a Queen and the gate of peace.

The way author described the culture, norms, and habit of the East is objective because the author himself is not an East but West. His representation of East can mislead people. According to Kluckhohn (1962) culture is human's life that includes social and groups value like religion, language, art, morality that can create attitude, perspective, way of thinking, and habit of life. Simply put, the East representation above can be false and need more comprehension.

\subsection{HOW THE OCCIDENT AUTHORS DESCRIBE THE WESTERN CHARACTER THROUGH CAESAR}

Shaw described Caesar as intelligence, patience, hard worker, kind, and idealism. When the Egypts preferred violence like cutting 
people's heads off, Caesar didn't like it.

Caesar: On my head be it, then; for it was well done. Rufio: had you set yourself in the seat of the judge, and with hateful ceremonies and appeals to the gods handed that woman over to some hired executioner to be slain before the people in the name of justice, never again would I have touched your hand without a shudder. But this was natural slaying: I feel no horror at it.

In here, Cleopatra and Rufio wanted to revenge to people who had killed Ftatateeta; Cleopatra's nurse. Caesar made sure that that murder of Ftatateeta was a coincidence and no need to kill other people. Caesar also described as kind person. He didn't have any revenge though to his enemies. According to him, men's live should not be to fools as below.

Caesar : No, by the gods! Would that it had been! Vengeance at least is human. No, I say: those severed right hands, and the brave Vercingetorix basely strangled in a vault beneath the Capitol, were (with shuddering satire) a wise severity, a necessary protection to the commonwealth, a duty of statesmanship-follies and fictions ten times bloodier than honest vengeance! What a fool was I then! To think that men's lives should be at the mercy of such fools!
Caesar: Vengeance! Vengeance!!

Oh, if I could stoop to vengeance, what would I not exact from you as the price of this murdered man's blood. (They shrink back, appalled and disconcerted.) Was he not my son-in-law, my ancient friend, for 20 years the master of great Rome, for 30 years the compeller of victory? Did not I, as a Roman, share his glory? Was the Fate that forced us to fight for the mastery of the world, of our making? Am I Julius Caesar, or am I a wolf, that you fling to me the grey head of the old soldier, the laurelled conqueror, the mighty Roman, treacherously struck down by this callous ruffian, and then claim my gratitude for it! (To Lucius Septimius) Begone: you fill me with horror.

Caesar also seen kind when he let go all his prisoners and smiled to them when all Romans court didn't agree of that action.

Also Caesar is intelligence and hard worker. Cleopatra said his father was a king and never worked and told Caesar not to work.

Caesar: I have work to do, Cleopatra.

Cleopatra : Work! What nonsense! You must remember that you are a King now: I have made you one. Kings don't work.

Caesar: Oh! Who told you that, little kitten? Eh?

Cleopatra : My father was King of Egypt; and he never worked. 
Ftatateeta also said that Caesar is like a witch because he didn't sleep and just worked all day

Ftatateeta: he is a magician. A magician can change their shape as they pleased. Everything about him is magical. He would not sleep in the golden chamber. He kept working like a slave all night.

Caesar is also patience when he kept teaching Cleopatra to be a Queen. He will not leave Egypt until Cleopatra became a queen when Caesar was forced to leave Egypt by Alexandrian.

Cleopatra : But if you go away, I shall not be Queen.

Caesar: I shall not go away until you are Queen.

Caesar: I speak to the Queen. Be silent. (To Cleopatra) Is this how your

servants know their places? Send her away; and you (to the slave) do as the Queen has bidden. (The slave lights the lamps. Meanwhile Cleopatra stands hesitating, afraid of Ftatateeta.) You are the Queen: send her away

Cleopatra : Ftatateeta, dear: you must go away-just for a little.

Caesar: You are not commanding her to go away: you are begging her. You are no Queen. You will be eaten. Farewell. (He turns to go.)

Cleopatra : No, no, no. Don't leave me.

Caesar : A Roman does not stay with queens who are afraid of their slaves.
Cleopatra : I am not afraid. Indeed I am not afraid.

All the way from example above, it is shown that Caesar is perfect. Caesar as the Roman ruler represented as the civilization Occident. It is shown from beginning until the end. How it is seen that the East needed his helps and he willed to help them. it is seen at that time the Egypt already colonized by Romans.

\section{CONCLUSION}

The conclusions can be taken from story of Caesar and Cleopatra drama. And then in findings itself the conclusion is. It is shown that most of the positive things belong to the Occident for instance they are intelligence, hard worker, patience, and kind whilst the East is seen as negative like barbaric, impatience, don't have good management, weak, and need other people. Based on Said's (1978) Orientalism, this drama shows two hegemonic purposes that represents the East as inferior and subordinate to the West. The occident saw it as legal thing to 'enlighten' the East for their lacks. The representation characters of the East and the West also seem biased because there is no seen the positive of the East. The author himself not East so that can mislead the image of the East.

\section{REFERENCES}

Creswell, J. W. (2014). Research Design, Qualitative Quantitative Appoaches. Book.

Daulay, R., \& Arianto, T. (2020). The 
Construction of Postcolonial Discourse In The Story Robohnya Surau Kami By Aa Navis. IdeBahasa, 2(1), 13-26. link

https://jurnal.idebahasa.or.id/i ndex.php/Idebahasa/article/vie w/36

Hasani, M. R. (2020). Extended Essay on Orientalism in The Painted Veil by William Somerset Maugham.

Kinanti, A. L., \& Daulay, R. (2020). Child Abuse Experienced By The Main Character In Rainbow Rowell's Eleanor And Park: A Psychosocial

Analysis. IdeBahasa, 2(2), 155164.

Link https://jurnal.idebahasa.or.id/i ndex.php/Idebahasa/article/vie w/48

Maliyana, Y. (2013). Edward Said's Orientalism and the Representation of the East in Gardens of Water by Alan Drew. Passage.

Moosavinia, S. R., Niazi, N., \& Ghaforian, A. (2011). Edward
Said's Orientalism and the Study of the Self and the Other in Orwell's Burmese Days. Studies in Literature and Language.

Murdock, G. P., \& Kluckhohn, R. (1962). Culture and Behavior: Collected Essays of Clyde Kluckhohn. American Sociological Review. https://doi.org/10.2307/20896 61

Pabiona, H. Y., \& Arianto, T. (2021). Floating Identity Reflected In Robert Olen Butler's Short Story "Cricket". Jurnal Basis, 8(2), 173-180. link https://ejournal.upbatam.ac.id/ index.php/basis/article/view/4 108

Said, E. (1978). Orientalism. New York: Penguin Books.

Snow, C., \& O'connor, C. (2016). Close Reading and Far-Reaching Classroom Discussion: Fostering a Vital Connection. Journal of Education.

https://doi.org/10.1177/00220

5741619600102 
Vol. 3 No. 2

December 2021

e- ISSN 2685 - 0559
Jusnal

Ide Bahasa

Inspirasi Dosen Bahasa dan Sastra 